\title{
Administration of Antenatal Corticosteroids: \\ Current State of Knowledge
}

Applikation antenataler Kortikosteroide: aktueller Wissensstand

(ㄷ) (1) $($ 웅

\author{
Authors \\ Richard Berger ${ }^{1}$, loannis Kyvernitakis ${ }^{2}$, Holger Maul ${ }^{2}$ \\ Affiliations \\ 1 Marienhaus Klinikum St. Elisabeth, Klinik für Gynäkologie \\ und Geburtshilfe, Neuwied, Germany \\ 2 Asklepios Kliniken Barmbek, Wandsbek und \\ Nord-Heidberg, Frauenkliniken, Hamburg, Germany
}

Key words

corticosteroids, preterm birth, dose, timing

Schlüsselwörter

Kortikosteroide, Frühgeburt, Dosis, Timing

\author{
received \\ 8.4. 2021 \\ accepted after revision \\ 20.7. 2021 \\ published online \\ 11.1.2022

\section{Bibliography} \\ Geburtsh Frauenheilk 2022; 82: 287-296 \\ DOI 10.1055/a-1555-3444 \\ ISSN 0016-5751 \\ (C) 2022. The Author(s).
}

This is an open access article published by Thieme under the terms of the Creative Commons Attribution-NonDerivative-NonCommercial-License, permitting copying and reproduction so long as the original work is given appropriate credit. Contents may not be used for commercial purposes, or adapted, remixed, transformed or built upon. (https://creativecommons.org/licenses/by-nc-nd/4.0/)

Georg Thieme Verlag KG, Rüdigerstraße 14,

70469 Stuttgart, Germany

\section{Correspondence}

Prof. Dr. med. Richard Berger

Marienhaus Klinikum St. Elisabeth, Akademisches Lehr-

krankenhaus der Universitäten Mainz und Maastricht,

Klinik für Gynäkologie und Geburtshilfe

Friedrich-Ebert-Straße 59, 56564 Neuwied, Germany

richard.berger@marienhaus.de

Deutsche Version unter:

https://doi.org/10.1055/a-1555-3444

\begin{abstract}
The administration of a single course of corticosteroids before week $34+0$ of gestation in cases with impending preterm birth is now standard procedure in obstetric care and firmly established in the guidelines of different countries. But despite the apparently convincing data, numerous aspects of this intervention have not yet been properly studied. It is still not clear which corticosteroid achieves the best results. There are very few studies on what constitutes an appropriate dose, circadian rhythms, the time frame in which corticosteroids are effective, and the balance between the risks and benefits of repeat administration. As the existing studies have rarely included patients before week $24+0$ of gestation, we have very little information on the possible benefits of administering corticosteroids before this timepoint. If corticosteroids are administered antenatally after week $34+0$ of gestation, the short-term benefit may be offset by the long-term adverse effect on psychomotor development. This present study summarizes the current state of knowledge regarding these issues.
\end{abstract}

\section{ZUSAMMENFASSUNG}

Die einmalige Gabe von Kortikosteroiden vor $34+0$ SSW bei drohender Frühgeburt ist ein Standard in der heutigen Geburtshilfe und in den Leitlinien der verschiedensten Länder fest verankert. Trotz der anscheinend überzeugenden Datenlage sind allerdings zahlreiche Teilaspekte zu dieser Intervention nur wenig geklärt. So war bisher offen, welches Kortikosteroid die optimale Wirkung erzielt. Es gibt kaum Studien zur Dosierung, zur zirkadianen Rhythmik, zum Zeitfenster der Wirksamkeit oder zur Nutzen-Schaden-Bilanz einer wiederholten Gabe. Da in den vorliegenden Studien selten Patientinnen vor 24 + 0 SSW eingeschlossen wurden, haben wir nur wenig Information zum möglichen Nutzen einer KortikosteroidApplikation vor diesem Zeitpunkt. Bei einer antenatalen Gabe von Kortikosteroiden nach 34 + 0 SSW stehen dem kurzfristigen Nutzen möglicherweise langfristige Beeinträchtigungen in der psychomotorischen Entwicklung gegenüber. Die vorliegende Arbeit fasst den derzeitigen Wissensstand zu diesen Fragen zusammen. 


\section{Introduction}

Nowadays, the antenatal administration of corticosteroids is an integral part of the management of pregnant women with impending preterm birth. As Liggins and Howie already showed in 1972, it significantly reduces perinatal morbidity and mortality [1]. Their observations have since been confirmed by numerous prospective randomized studies and were recently summarized in a Cochrane review published in 2020 [2]. The administration of a single course of corticosteroids before week $34+0$ of gestation in cases with impending preterm birth is part of standard modern obstetric care and firmly established in the guidelines of different countries ( $\triangleright$ Table 1) [3-6].

But although the available data appears to be convincing, numerous aspects of this intervention have not been resolved. It is still unclear which corticosteroid achieves the best outcome. There are very few studies on doses, circadian rhythms, the time frame in which administration of corticosteroids is effective, and the balance between the risks and benefits of repeat administration. As very few patients have been included in studies before week $24+0$ of gestation, we have no information on the possible benefits of corticosteroid administration prior to this timepoint. This is a problem, given the fact that perinatal medicine is increasingly offering a chance of survival to even very young children. On the other hand, the short-term benefit of administering corticosteroids in cases of imminent preterm birth after week $34+0$ of gestation may be offset by a potential long-term impairment to the children's psychomotor development. This overview provides a summary of the current state of knowledge regarding these issues.

\section{Literature Search}

A selective literature search was carried out up in PubMed until March 2021 using the keywords "corticosteroid", "preterm birth", "preterm delivery". The relevant prospective randomized studies, reviews and meta-analyses were selected. Cross-references to other important works were also considered.

\section{Pharmacology}

The external administration of corticosteroids aims to "bring forward" the endogenous physiological increase in corticosteroid levels which occurs in late pregnancy and which promotes the maturation of various fetal organs and prepares the fetus for life postpartum. Nowadays, hospitals use betamethasone or dexamethasone for this. These are fluorinated synthetic corticosteroids which cross the placenta easily as they are not a substrate for 11- $\beta$ hydroxysteroid dehydrogenase [7].

Betamethasone is administered by intramuscular injection at a dosage of $2 \times 12 \mathrm{mg}$ ( $6 \mathrm{mg}$ betamethasone phosphate and $6 \mathrm{mg}$ betamethasone acetate) at an interval of $24 \mathrm{~h}$. The betamethasone in the phosphate compound is released more quickly and contributes to rapid enrichment whereas the betamethasone in the acetate compound is hydrolyzed more slowly [1]. The maximum betamethasone concentration in maternal serum occurs after $1 \mathrm{~h}$, whereas the peak fetal concentration occurs $1-2 \mathrm{~h}$ later. The half-life of betamethasone in the maternal circulation is 6 hours and 12 hours in the fetal circulation. The fetal/maternal concentration ratio is 0.37 . No traces of betamethasone are detectable in either the maternal or fetal circulation $48 \mathrm{~h}$ after the second injection. Dexamethasone is administered 4 times at $12 \mathrm{~h}$ intervals at a dose of $6 \mathrm{mg}$; this avoids the high peak concentra-

- Table 1 International guidelines on the administration of antenatal corticosteroids to treat impending preterm birth.

\begin{tabular}{|c|c|c|c|c|}
\hline Guideline & $\begin{array}{l}24+0-34+0 \\
\mathrm{GW}\end{array}$ & $<24+0 \mathrm{GW}$ & $>34+0 \mathrm{GW}$ & Repeat administration \\
\hline $\begin{array}{l}\text { ACOG Committee Opinion } \\
\text { No. } 713 \text { [4] }\end{array}$ & Single cycle & $\begin{array}{l}\text { Individual approach } \\
\text { from GW } 23+0 \text { to } \\
\text { GW } 23+6\end{array}$ & $\begin{array}{l}\text { Single cycle between } \\
\text { GW } 34+0 \text { and GW } 36+6 \\
\text { if no corticosteroids were } \\
\text { previously administered }\end{array}$ & $\begin{array}{l}\text { Consider administering repeat } \\
\text { cycle depending on the risk of } \\
\text { preterm birth } \\
\text { At the earliest } 7 \text { days after the last } \\
\text { administration } \\
\text { No more than } 2 \text { cycles in total }\end{array}$ \\
\hline $\begin{array}{l}\text { NICE Guideline Preterm Labour } \\
\text { and Birth [3] }\end{array}$ & Single cycle & $\begin{array}{l}\text { Individual approach } \\
\text { from GW } 23+0 \text { to } \\
\text { GW } 23+6\end{array}$ & $\begin{array}{l}\text { Consider administering } \\
\text { single cycle between } \\
\text { GW } 34+0 \text { and GW } 35+6\end{array}$ & $\begin{array}{l}\text { Consider administering repeat } \\
\text { cycle depending on the risk of } \\
\text { preterm birth }\end{array}$ \\
\hline $\begin{array}{l}\text { No. } 364 \text { - Antenatal Cortico- } \\
\text { steroid Therapy for improving } \\
\text { Neonatal Outcomes Canada [5] }\end{array}$ & $\begin{array}{l}\text { Single cycle } \\
\text { up to GW } 34+6\end{array}$ & $\begin{array}{l}\text { Individual approach } \\
\text { from GW } 22+0 \text { to } \\
\text { GW } 23+6\end{array}$ & $\begin{array}{l}\text { Consider administering } \\
\text { single cycle between } \\
35+0 \text { und } 36+6\end{array}$ & $\begin{array}{l}\text { Consider administering repeat } \\
\text { cycle depending on the risk of } \\
\text { preterm birth }\end{array}$ \\
\hline $\begin{array}{l}\text { Prevention and Therapy of } \\
\text { Preterm Birth 015-025 [6] } \\
\text { Guideline of the German, } \\
\text { Austrian and Swiss Societies of } \\
\text { Gynecology and Obstetrics }\end{array}$ & Single cycle & $\begin{array}{l}\text { Individual approach } \\
\text { from GW } 22+0 \text { to } \\
\text { GW } 23+6\end{array}$ & $\begin{array}{l}\text { No antenatal cortico- } \\
\text { steroids after GW } 34+0\end{array}$ & $\begin{array}{l}\text { Administer a repeat cycle only if } \\
\text { there is a very high risk of preterm } \\
\text { birth before GW } 29+0 \\
\text { No more than } 2 \text { cycles in total }\end{array}$ \\
\hline
\end{tabular}


tions which are observed with the betamethasone regimen but results in higher drug levels over longer periods of time [8].

As the maximum concentration with intramuscular administration already occurs after $1 \mathrm{~h}$, intravenous administration makes little sense. Moreover, experimental data has shown that fetal serum levels must be at least $1 \mathrm{ng} / \mathrm{ml}$ for $48 \mathrm{~h}$ to induce lung maturation. This can be best achieved if the drug is administered by intramuscular injection. There is very little data available on the oral administration of corticosteroids. An older study, which compared intramuscular injection of dexamethasone with oral administration, found a significantly increased incidence of neonatal sepsis when the corticosteroid was administered orally [9].

Both betamethasone and dexamethasone increase surfactant synthesis, improve pulmonary compliance, increase maximum lung volume, and lead to a better gas exchange and therefore a lower incidence of respiratory distress syndrome (RDS) [8]. The intraventricular hemorrhage rate and the incidence of necrotizing enterocolitis (NEC) are also lower, partly as a result of improved respiration, partly because of the direct effect of corticosteroids on the maturation of various organ systems $[8,10,11]$. More than 300 genes which are regulated by corticosteroids have been identified to date [12].

\section{Corticosteroids From Week $24+0$ to Week $34+0$ of Gestation}

The administration of a single cycle of corticosteroids to patients with impending preterm birth before week $34+0$ of gestation has been included in many different guidelines all over the world [36]. The last Cochrane review on this topic was published in 2020. The data of 11272 women with 11925 children were evaluated. According to the data, corticosteroids reduce perinatal mortality (RR 0.85 , 95\% Cl: 0.77-0.93) as well as the incidence of RDS (RR 0.71, 95\% Cl: 0.65-0.78) and intraventricular hemorrhage (IVH) (RR $0.58,95 \% \mathrm{Cl}: 0.45-0.75)$. They have almost no impact on birth weight (mean difference [MD] - 14.02 g, 95\% Cl: - 33.795.76) [2].

The impact on the long-term development of the children is less well known, as very few follow-up studies have been designed. There is a tendency towards a reduction of developmental delay (RR 0.48, 95\% Cl: 0.24-1.00) and of cerebral palsy (RR 0.64, 95\% Cl: 0.35-1.03). However, fewer than 1000 children were available for this analysis [10].

The data on patients with multiple pregnancy is also very limited. The Cochrane meta-analysis of 2017 observed no reduction in RDS (RR 0.90, 95\% Cl: 0.67-1.22), IVH (RR 0.39, 95\% Cl: $0.07-$ 2.06 ) or neonatal mortality (RR $0.79,95 \% \mathrm{Cl}$ : 0.39-1.61) after antenatal administration of corticosteroids in cases with impending preterm birth before week 34 of gestation. However, only a very small number of patients were included in this meta-analysis, and this aspect has therefore not been followed up here [10].

\section{The Choice of Corticosteroid}

A systematic review, published in 2013, which compared the effects of betamethasone and dexamethasone on perinatal morbidity and mortality found no differences between the two substances, with the exception of a slightly lower rate of intraventricular hemorrhage with dexamethasone (RR $0.44,95 \% \mathrm{Cl}: 0.21-$ 0.92) [13]. However, the review did not include information on the long-term development of these infants or data on maternal morbidity.

The ASTEROID trial was launched to compare outcomes for dexamethasone and betamethasone. This prospective, randomized, double-blind multicenter study included 1346 patients with impending preterm birth before week $34+0$ of gestation. 679 patients received $2 \times 12 \mathrm{mg}$ dexamethasone and 667 received $2 \times 12 \mathrm{mg}$ betamethasone administered antenatally by intramuscular injection at an interval of $24 \mathrm{~h}$. There was no difference in the primary study endpoint "death or neurosensory disability at the age of 2 years" between the two groups (RR 0.97, 95\% Cl: 0.83-1.13). No differences were found in perinatal morbidity rates including the rate of intraventricular hemorrhage, and there were likewise no differences in maternal morbidity rates. Only the cesarean section rate was significantly lower in the dexamethasone group, but no medical explanation was proposed for this (RR 0.84, 95\% Cl: 0.75-0.94) ( Table 2) [14].

The most recent meta-analysis on this topic, which included data from 45 studies covering 11227 women and 11878 children, found no differences with regard to perinatal and maternal morbidity rates between dexamethasone and betamethasone. The meta-analysis did not investigate the incidence of cesarean section [15].

\section{Dosage}

The dosage proposed by Liggins consisted of $2 \times 12 \mathrm{mg}$ betamethasone administered intramuscularly at an interval of $24 \mathrm{~h}$. This covers around $75 \%$ of all fetal glucocorticoid receptors and therefore probably achieves the maximum activation of all downstream genes [16]. In a subsequent study, Howie and Liggins were unable to achieve any further improvement in neonatal morbidity rates by doubling the dose [17]. This has also been confirmed by more recent experimental studies [18]. Moreover, it was found that higher doses of corticosteroids can negatively affect the programming of fetal developmental and metabolic processes [19].

In contrast to the above studies, experimental studies on ovine fetuses suggest that administration of a single $12 \mathrm{mg}$ dose of betamethasone may be as effective for the maturation of fetal lungs as the administration of two doses $(2 \times 12 \mathrm{mg})$ at an interval of $24 \mathrm{~h}[20,21]$. This consideration led to the development of the BETADOSE trial, a prospective randomized, double-blind non-inferiority study. A total of 3244 patients with impending preterm birth before week 32 of gestation were recruited into this study. After receiving an initial dose of $12 \mathrm{mg}$ betamethasone, patients were randomized and $24 \mathrm{~h}$ later received either another $12 \mathrm{mg}$ of betamethasone or placebo. The primary study endpoint was the incidence of RDS, defined as the need for surfactant replacement within $48 \mathrm{~h}$ after birth. The RDS rate after two administrations of 
- Table 2 Comparison of dexamethasone and betamethasone (ASTEROID trial). The impact of $2 \times 12 \mathrm{mg}$ dexamethasone was compared with the impact of $2 \times 12 \mathrm{mg}$ betamethasone on the mortality/neurosensory development of the children at the age of 2 years and on neonatal and maternal morbidity rates [14].

\begin{tabular}{|c|c|c|c|c|}
\hline & Dexamethasone & Betamethasone & RR & $95 \% \mathrm{Cl}$ \\
\hline & $n(\%)$ & n (\%) & & \\
\hline \multicolumn{5}{|l|}{ Primary study endpoint } \\
\hline Death or neurosensory disability at the age of 2 years & $198 / 603(33 \%)$ & 192/591 (32\%) & 0.97 & $0.83-1.13$ \\
\hline \multicolumn{5}{|l|}{ Neonatal } \\
\hline Intraventricular hemorrhage & $34 / 752(5 \%)$ & $32 / 737(4 \%)$ & 1.09 & $0.67-1.78$ \\
\hline Periventricular leukomalacia & $2 / 752(<1 \%)$ & $2 / 737(<1 \%)$ & NA & NA \\
\hline Respiratory distress syndrome & $183 / 752(24 \%)$ & $174 / 737(24 \%)$ & 1.03 & $0.87-1.13$ \\
\hline \multicolumn{5}{|l|}{ Maternal } \\
\hline Infections & $125 / 679(18 \%)$ & $132 / 667(20 \%)$ & 0.95 & $0.77-1.18$ \\
\hline Cesarean section & $295 / 679(43 \%)$ & $346 / 667(52 \%)$ & 0.84 & $0.75-0.93$ \\
\hline Postpartum hemorrhage & $128 / 679(19 \%)$ & $141 / 667(21 \%)$ & 0.87 & $0.71-1.08$ \\
\hline
\end{tabular}

- Table 3 Comparison of a single dose of $12 \mathrm{mg}$ betamethasone and two doses administered at an interval of 24 hours (BETADOSE trial). The trial compared the effect of administering a single dose of $12 \mathrm{mg}$ betamethasone with the effect of two doses administered at an interval of 24 hours on neonatal mortality and morbidity [22].

\begin{tabular}{|c|c|c|c|c|}
\hline & $\begin{array}{l}1 \times 12 \mathrm{mg} \\
\text { betamethasone }\end{array}$ & $\begin{array}{l}2 \times 12 \mathrm{mg} \\
\text { betamethasone }\end{array}$ & $\begin{array}{l}\text { Risk difference } \\
(95 \% \mathrm{Cl})\end{array}$ & $\begin{array}{l}\text { P-value for } \\
\text { superiority }\end{array}$ \\
\hline & n (\%) & $n(\%)$ & & \\
\hline \multicolumn{5}{|l|}{ Primary study endpoint } \\
\hline Respiratory distress syndrome & $304 / 1508(20.2 \%)$ & $268 / 1484(18.1 \%)$ & $2.2(-0.7-4.9)$ & \\
\hline \multicolumn{5}{|l|}{ Secondary study endpoints } \\
\hline Neonatal mortality & $54(3.4 \%)$ & $50(3.2 \%)$ & & 0.68 \\
\hline Intraventricular hemorrhage grade III-IV & $17(1.1 \%)$ & $27(1.7 \%)$ & & 0.13 \\
\hline Periventricular leukomalacia & $20(1.3 \%)$ & $25(1.6 \%)$ & & 0.46 \\
\hline Necrotizing enterocolitis grade $\geq \mathrm{II}$ & $31(2.0 \%)$ & $20(1.3 \%)$ & & 0.12 \\
\hline Bronchopulmonary dysplasia & $66(4.3 \%)$ & $73(4.7 \%)$ & & 0.55 \\
\hline Neonatal survival without severe morbidity & $1230(78.6 \%)$ & $1270(80.9 \%)$ & & 0.11 \\
\hline
\end{tabular}

betamethasone was $18.1 \%$ and therefore significantly lower than in the study group (20.1\%). However, there were no other differences in perinatal morbidity or mortality between the two groups ( Table 3) [22].

\section{Timing of Administration}

The release of maternal cortisol follows a circadian rhythm. If this rhythm is disturbed, for example by stress, sleep deprivation, or a shift in the time zone, then experimental and epidemiological data have shown that the risk of affected children developing psychological disorders in later life increases [23]. But this type of impairment can also arise from the administration of a corticosteroid during pregnancy, which does not take account of maternal endogenous circadian rhythms. Mice whose dams were injected with glucocorticoids out of phase with their endogenous rhythms showed significantly stronger behavioral anxiety and were less able to deal with stress situations. It appears that the dyssynchronous administration of corticosteroids increases the concentrations of glucocorticoid receptors in the hypothalamus. REVERB $\alpha$, a "clock protein" plays an important role in this. Out-of-phase administration resulted in dysregulation of the hypothalamic-pituitary-adrenal axis, which led to the described behavioral disorders in the animals [24]. A retrospective observational study of fiveyear-old children also found significant impairments in dealing with stress situations. There was also a trend to a higher incidence 
- Table 4 Incidence of respiratory distress syndrome depending on the interval between corticosteroid administration and delivery [25].

\begin{tabular}{|c|c|c|c|c|c|c|}
\hline & \multicolumn{2}{|c|}{ Betamethasone } & \multicolumn{2}{|c|}{ Control } & \multirow[t]{2}{*}{ RR } & \multirow[t]{2}{*}{$95 \% \mathrm{Cl}$} \\
\hline & $\mathrm{n}$ & RDS (\%) & $\mathbf{n}$ & RDS (\%) & & \\
\hline \multicolumn{7}{|c|}{ Interval to delivery } \\
\hline$<24 \mathrm{~h}$ & 260 & 26.1 & 257 & 28.7 & 0.87 & $0.66-1.15$ \\
\hline$<48 \mathrm{~h}$ & 171 & 22.2 & 203 & 33.5 & 0.63 & $0.43-0.92$ \\
\hline 1-7 days & 563 & 10.1 & 547 & 23.0 & 0.46 & $0.35-0.60$ \\
\hline$>7$ days & 498 & 6.4 & 490 & 7.6 & 0.82 & $0.53-1.28$ \\
\hline
\end{tabular}

RR: relative risk; $95 \% \mathrm{Cl}: 95 \%$ confidence interval

of hyperactivity, anxiety and a lack of self-confidence [24]. Wherever possible, circadian rhythms should therefore be considered when administering corticosteroids. Cortisol serum levels are highest between 6 and 8 o'clock in the morning, after which they decline during the day and drop to their minimum level between 0 and 6 o'clock at night. However, despite the importance of circadian rhythms, the administration of antenatal corticosteroids must not be delayed if corticosteroids are urgently required.

\section{Timing und Interval}

As a meta-analysis published in 2006 showed, no impact on RDS has been observed before $24 \mathrm{~h}$ after the initial administration of betamethasone (RR $0.87,95 \% \mathrm{Cl}: 0.66-1.15)$; the effect only occurs < 48 h (RR 0.63, 95\% Cl: 0.43-0.92) ( Table 4) [25]. Given this context, it made sense to attempt to investigate whether it would be possible to shorten the administration interval for betamethasone to achieve faster lung maturation. In 2012, Khandelwal and colleagues published a prospective, randomized study to test this hypothesis. Their study compared the administration of two doses of betamethasone, given at an interval of $24 \mathrm{~h}$ between doses, with a $12 \mathrm{~h}$ interval. A total of 228 patients were recruited into the study. Patients were randomized $2: 1$. The shorter administration interval had no impact on the RDS rate (36.5 vs. $37.3 \%)$ or the perinatal mortality (11.9 vs. $12.8 \%)$ of treated infants. The rate of necrotizing enterocolitis was even significantly higher (0.0 vs. $6.2 \%, p=0.03$ ) (Khandelwal et al., 2012) [26]. Irrespective of this, an evaluation of the EPICE cohort suggests that in-hospital mortality may already begin to decrease from $3 \mathrm{~h}$ after the first administration of betamethasone [27].

In addition, no further reduction of RDS could be detected $>7$ days after corticosteroid administration (RR $0.82,95 \% \mathrm{Cl}$ : 0.53-1.28) ( Table 4) [25]. In contrast, Liebowitz and Clyman found in a retrospective analysis that extremely preterm babies born before week 28 of gestation who were delivered $>10$ days after the first administration of a corticosteroid had a more than two times higher rate of intraventricular hemorrhage (17\% vs. $7 \%$; AOR 4.16, 95\% Cl: 1.59-10.87). However, if the mother had received a second cycle for lung maturation, this rate was only $8 \%$ and did not differ from that of infants born $<10$ days after the first administration [28]. These studies confirm how important the correct timing of administration for lung maturation is.
- Table 5 Interval between corticosteroid administration and delivery depending on the indication, based on [29].

\begin{tabular}{|l|l|l|}
\hline & \multicolumn{2}{|l|}{$\begin{array}{l}\text { Interval: from corticosteroid } \\
\text { administration to delivery }\end{array}$} \\
\hline & $\mathbf{2} \mathbf{2 4} \mathbf{h} \mathbf{- 7}$ days & $\begin{array}{l}<\mathbf{2 4} \mathbf{h} \text { or } \\
\mathbf{> 7} \text { days }\end{array}$ \\
\hline & $\mathbf{n ( \% )}$ & $\mathbf{n}(\%)$ \\
\hline Indication & & \\
\hline Preterm rupture of membranes & $60(46.2)$ & $70(53.8)$ \\
\hline Preterm labor & $49(36.3)$ & $86(63.7)$ \\
\hline Pregnancy-induced hypertension & $90(62.1)$ & $55(37.9)$ \\
\hline Asymptomatic cervical shortening & $6(11.8)$ & $45(88.2)$ \\
\hline $\begin{array}{l}\text { Fetal growth restriction, } \\
\text { oligohydramnios }\end{array}$ & $13(36.1)$ & $23(63.9)$ \\
\hline $\begin{array}{l}\text { Vaginal bleeding, placental } \\
\text { separation }\end{array}$ & $15(20.6)$ & $58(79.5)$ \\
\hline
\end{tabular}

In a retrospective analysis, Levin and colleagues investigated the timing of lung maturation in the context of different indications for preterm delivery between week 24 and week 34 of gestation [29]. Data from 630 patients were included in this study. Irrespective of the respective indication, only $40 \%$ of cases could be delivered within the optimal time frame after administration $(24 \mathrm{~h}$ - 7 days). As expected, the optimal timing of delivery was easiest to achieve in women with hypertension (62.1\%); patients who were not in labor but had cervical shortening, cervical opening, or a positive fibronectin test came off worst (11.8\%) ( $\triangleright$ Table 5 ) [29]. This can be ascribed to the poor positive predictive value of cervical length measurement and of different biochemical tests to evaluate the risk of preterm birth [30]. This observation is supported by further studies. In a retrospective examination, Adams and colleagues showed that it was far more difficult to achieve optimal timing of lung maturation ( $24 \mathrm{~h}-7$ days) in an infant born $<37$ weeks of gestation who had to be delivered because of fetal indications than in cases when delivery was necessary because of a maternal indication (fetal-optimal vs. non-optimal: 24 vs. $76 \%$; maternal-optimal vs. non-optimal: 60 vs. 40\%) [31]. Makhija et al. reported similar findings [32]. 
- Table 6 Development of children at the age of 5 years after multiple administrations of corticosteroids compared to administration of a single cycle (MACS trial). Children who were born at term after receiving multiple administrations of corticosteroids ( $\geq 37+0$ weeks of gestation) had significantly more neurosensory developmental disorders compared to infants born preterm ( $<37+0$ weeks of gestation) [37].

\begin{tabular}{|c|c|c|c|c|c|}
\hline & \multicolumn{2}{|c|}{$\begin{array}{l}\text { Children born preterm } \\
(n=1257)\end{array}$} & \multicolumn{2}{|c|}{$\begin{array}{l}\text { Children born at term } \\
(n=462)\end{array}$} & \multirow[t]{2}{*}{$\begin{array}{l}\text { p-value of preterm } \\
\text { vs. at-term infants }\end{array}$} \\
\hline & OR (95\% Cl) & p-value & OR $(95 \% \mathrm{Cl})$ & p-value & \\
\hline \multicolumn{6}{|l|}{ Primary study endpoint } \\
\hline Death or neurological disability at the age of 5 years & $0.87(0.67-1.14)$ & 0.32 & $1.69(1.04-2.77)$ & 0.04 & 0.02 \\
\hline \multicolumn{6}{|l|}{ Secondary study endpoint } \\
\hline Death & $0.91(0.58-1.44)$ & 0.66 & $0.58(0.52-6.47)$ & 0.65 & 0.72 \\
\hline Neuromotor disability & No convergence & & No convergence & & \\
\hline Neurosensory disability & $0.84(0.55-1.29)$ & 0.43 & $3.70(1.57-8.75)$ & 0.004 & 0.005 \\
\hline Neurocognitive disability & $0.89(0.62-1.28)$ & 0.53 & $1.31(0.75-2.29)$ & 0.35 & 0.31 \\
\hline
\end{tabular}

It follows, therefore, that the decision to administer antenatal corticosteroids should only be made if there is a high risk of preterm birth within the next 7 days. A twin pregnancy alone or fetal growth restriction is insufficient.

\section{Repeat Administration for Lung Maturation}

A possible solution for this problem could be the administration of a so-called rescue cycle. Crowther and colleagues summarized the results of 11 prospective randomized studies on repeated antenatal administration of corticosteroids in a meta-analysis of individual patients' data [33]. The data of 4857 women and 5915 children were included in their evaluation. The age of gestation at recruitment ranged from week 27.4 to week 30.2 of gestation. There were no differences in serious outcomes (RR $0.92,95 \% \mathrm{Cl}$ : $0.82-1.04$ ), which was defined as death, severe RDS, IVH $\geq$ grade 3 , chronic pulmonary disease, necrotizing enterocolitis, retinopathy $\geq$ grade 3 or periventricular leukomalacia (PVL). The rate of infants who required respiratory support was significantly lower after repeat administration of corticosteroids (RR 0.91, 95\% Cl: $0.85-0.97)$. The number needed to treat was 21 (95\% Cl: $14-$ $41)$. However, the z-score of the birth weights of infants who received repeated administrations of corticosteroids was also significantly lower $(-0.12,95 \% \mathrm{Cl}:-0.18--0.06)$. The difference was even higher following more lung maturation cycles [33]. Although the meta-analysis by Crowther et al. found no difference for the combined variable "death or neurosensory impairment", nevertheless there are some concerns that the repeated administration of corticosteroids can impair the development of affected children.

There are a number of retrospective studies and results from animal experiments which show that a repeated administration of glucocorticoids can lead to growth restriction and neuronal damage of the fetus. Behavioral disorders at a later stage of development have also been reported [34-36]. Data from the MACS trial, the largest prospective, randomized study which investigated the impact of a repeated induction of lung maturation on the development of children compared to the administration of a single cycle of corticosteroids, point to the same conclusion. The primary study endpoints after 5 years were death or impairment of neurological development in one of the following areas: neuromotor skills, neurosensory skills, neurocognition. No significant differences with regard to these variables were found between the groups. What was interesting, however, was a subgroup analysis of infants who had received multiple administrations for lung maturation. The primary study endpoint for infants born at term was significantly poorer compared to children born preterm (OR 1.69, 95\% Cl: 1.04-2.77). On closer observation, these differences were found to manifest particularly with regard to neurosensory characteristics (blindness, deafness, need for visual or hearing aids) (OR 3.70, 95\% Cl: 1.57-8.75) ( Table 6) [37]. The NICHD study also reported an increased rate of children with cerebral palsy after repeated doses of corticosteroids ( 2.9 vs. $0.5 \%$; RR 5.7, 95\% Cl: 0.7-46.7). Even though this difference was not significant, it is nevertheless not possible to exclude the possibility of corticosteroids impairing neurological development. It is also worth mentioning that five of the six affected children in the group which received repeated corticosteroid administrations were born after week 34 of gestation and that all six children had received at least four cycles [38].

Given this data, the question is, under which circumstances should corticosteroid administration for lung maturation be repeated if there is still a high risk of preterm birth after a single course of corticosteroids. On the one hand, the repeated administration of corticosteroids reduces the short-term need for respiratory support in preterm children; on the other hand, repeated administrations may lead to growth restriction and long-term impairment of neurological development. Zephyrin and colleagues carried out an interesting analysis which focused on this issue [39]. Using a Markov model, they contrasted the improved neonatal outcomes after repeated glucocorticoid administrations with the risk of fetal growth restriction. Their calculations were based on the results of a study by the Eunice Kennedy Shriver National Institute of Child Health and Human Development Maternal-Fetal Medicine Units Network [40]. After week $29+0$ of gestation, repeated courses of corticosteroids to induce fetal lung maturation 
were associated with increased disadvantages for the children [39]. Administering a repeat course to induce lung maturation should therefore be limited to patients with a very low gestational age ( $\leq 29+0$ weeks of gestation) [6]. The majority of international guidelines also only recommend a single repeat course for lung maturation [3-6]. As gender is an important variable, particularly in extremely preterm birth, and has a significant impact on neonatal morbidity and mortality [41], it is worth considering whether, in future, the limit of $29+0$ weeks of gestation for a repeat administration of corticosteroids also needs to be discussed with respect to the infant's gender.

\section{Corticosteroids and Late Preterm Birth (>34 Weeks of Gestation)}

Even if the respiratory morbidity of preterm infants decreases significantly after 34 weeks of gestation, it is still much higher than that of children born at term [42]. The logical step was therefore to investigate whether an administration of corticosteroids even after 34 weeks of gestation would result in a further decrease in infant morbidity.

The ALPS trial was designed to clarify this point [43]. A total of 2827 women who were about to give birth between week $34+0$ and week $36+5$ of gestation were included in this prospective randomized study. Inclusion criteria were a cervix dilated by at least $3 \mathrm{~cm}$ and preterm labor, premature rupture of membranes or a medical requirement for the baby to be delivered very soon (e.g., pre-eclampsia, placental insufficiency, etc.). The women in the study group received $2 \times 12 \mathrm{mg}$ betamethasone injected intramuscularly at an interval of 24 hours, while the women in the control group received placebo. Primary study endpoints were need for respiratory therapy or stillbirth or neonatal mortality.

Only around $60 \%$ of the women received two betamethasone injections; around $85 \%$ were delivered before week $37+0$ of gestation. This underlines how important it is to weigh up the indications before administering medication for lung maturation. The primary study endpoint was significantly lower in the betamethasone group (RR $0.80,95 \% \mathrm{Cl} .0 .66-0.97$ ) as was the need for surfactant replacement (RR 0.59, 95\% Cl: 0.37-0.96) and the rate of bronchopulmonary dysplasia (RR 0.22 , 95\% Cl: 0.02-0.92). However, the number needed to treat for bronchopulmonary dysplasia was 200. Because of the administration of betamethasone, the rate of neonatal hypoglycemia in the study group was significantly increased, although this was expected (RR 1.60, 95\% Cl: 1.371.87) [43]. This was also confirmed in subsequent meta-analyses (RR 1.61, 95\% Cl: 1.38-1.87) [44,45].

Although the results of the ALPS trial have been welcomed enthusiastically by the American College of Obstetricians and Gynecologists [4], caution is still advised, as no long-term examinations of these children have been carried out yet and the impact of the administered corticosteroids on their further neurological development is still unclear.

In this context, it is also important to discuss the ASTECS trial, in which mothers undergoing elective cesarean section at term were given $2 \times 12 \mathrm{mg}$ betamethasone antenatally. This intervention significantly reduced the rate of children admitted to a pedi- atric unit and monitored for RDS (RR 0.46, 95\% Cl: 0.23-0.93) [46]. About $50 \%$ of mothers were questioned more than ten years later about the subsequent psychosocial development and health of their children. No significant differences were observed between the groups. However, when schools carried out their assessments, significantly more children in the treatment group were classified into the lower performance quartile by their teachers ( 17.7 vs. $8.5 \%, p=0.03$ ) and fewer children were classified into the top performance quartile [47]. These data also show how long children whose mothers were given corticosteroids should be followed up to obtain a clear picture of the long-term consequences of this intervention.

It is even possible that mental impairment and behavioral disorders occur more frequently in children who were born at term after the administration of a single cycle of corticosteroids compared to children born at term who did not receive corticosteroids during pregnancy. This is certainly what has been suggested by a Finnish registry study (HR 1.47, 95\% Cl: 1.36-1.69). To take account of the potential bias created by socioeconomic effects, the comparison was also calculated for siblings and the difference remained significant (HR 1.38, 95\% Cl: 1.21-1.58) [48].

\section{Corticosteroids and Extreme Preterm Birth (Week $22+0$ to $23+6$ of Gestation)}

Between week 22 and week 26 of gestation, the fetal lung is in its canalicular phase of development. After the bronchioles have developed, the alveolar epithelium begins to differentiate and gradually becomes thinner, facilitating gas exchange with the capillaries. Surfactant can already be detected in type 2 alveolar cells and is secreted in the alveolar space. These developmental steps can be accelerated by corticosteroids, as has been shown in experimental studies (Schnittny and Burri et al., 2008) [49].

The rapid advances in perinatal medicine mean that we are now increasingly moving into areas which, up until a short time ago, were unimaginable. For a long time, week $24+0$ of gestation was considered the limit of viability for the delivery of a live born infant, but now many perinatal centers carry out interventions already in the 23 rd or even the 22 nd week of gestation. This requires an intensive discussion between the affected parents and the respective perinatology team, which is discussed in more detail in the German-language guideline "Preterm Infants on the Edge of Viability" [50].

The obvious question in this context is, when is the right time to start with the administration of corticosteroids to induce fetal lung maturation. Prospective randomized studies cannot answer this question. They were designed at a time when children of this gestational age had almost no chance of survival and were therefore not considered when designing the study. Since then, however, a number of cohort studies have been published on this topic [51-61].

The most comprehensive of these studies analyzed the data of children with birth weights from 401 to 1000 grams, who were born between 1993 and 2009 in one of the 23 perinatal centers of the National Institute of Child Health and Human Development Neonatal Research Network [61]. A total of 10451 children were 
registered in this period. Their gestational ages ranged from week 22 to week 25 of gestation. $86.5 \%$ of the surviving children ( $n=4924)$ were re-examined after $18-22$ months. Death or impaired neurological development was significantly lower after the administration of corticosteroids in children born in the 23rd week (AOR 0.58, 95\% Cl: 0.42-0.80), the 24th week (AOR 0.62, $95 \% \mathrm{Cl}: 0.49-0.78)$ and the 25th week of gestation (AOR 0.61, $95 \% \mathrm{Cl}: 0.50-0.74)$. For infants born in the 22 nd week of gestation, a benefit was only found with respect to the combined outcome "death or NEC" (AOR 0.54, 95\% Cl: 0.30-0.97) [61]. A more recent Norwegian cohort study also confirmed the benefit of antenatal corticosteroid administration in these very immature infants (OR 3.5, 95\% Cl: 1.4-8.8) [54]. A meta-analysis published in 2017, which reported a reduction of neonatal mortality and a lower incidence of IVH and PVL after the administration of antenatal corticosteroids in infants below the age of 25 weeks of gestation, came to the same conclusion [62].

In the event of a preterm birth at the edge of viability, most international guidelines recommend that affected parents be offered open-ended, interdisciplinary and interprofessional counselling to ensure shared participatory decision-making [3-5]. If the parents opt for a maximum intervention with an extreme preterm birth in week $22+0$ to $23+6$ of gestation, then corticosteroids should be administered antenatally [6].

\section{Summary}

A single cycle of corticosteroids administered before week $34+0$ of gestation to treat impending preterm birth is now considered a standard obstetric procedure and is firmly established in the guidelines of a number of different countries. According to the current state of knowledge, betamethasone and dexamethasone are equally effective. A single dose of betamethasone results in a slightly higher incidence of RDS compared to the administration of two doses at an interval of $24 \mathrm{~h}$, but there were no differences with regard to other parameters of neonatal morbidity. Corticosteroids should, if possible, be administered in the morning before midday. There are some indications that a dyssynchronous administration of corticosteroids which are not attuned to the mother's endogenous rhythm can have a negative impact on the capacity of affected infants to deal with stressful events in later life. Neonatal morbidity only decreases significantly if delivery occurs within the optimal period ( $>24 \mathrm{~h}-7$ days) after administration of the corticosteroid. Some data have also shown that infants who are born at term, i.e., from week $37+0$ of gestation onward, after antenatal administration of corticosteroids may suffer mental impairment and behavioral disorders. This means that the decision to administer corticosteroids antenatally must be considered very carefully. A theoretical calculation weighing up the benefits against the disadvantages suggests that a repeat administration of corticosteroids is only useful in cases of imminent preterm birth before week $29+0$ of gestation. No corticosteroids should be administered in cases of impending preterm birth after week 34 of gestation as long as there is no data on the long-term development of affected children. If a maximum intervention is planned in a case of impending preterm birth before week 24 of gestation, then the administration of corticosteroids will improve neonatal morbidity and mortality.

\section{Conflict of Interest}

The authors declare that they have no conflict of interest.

\section{References}

[1] Liggins GC, Howie RN. A controlled trial of antepartum glucocorticoid treatment for prevention of the respiratory distress syndrome in premature infants. Pediatrics 1972; 50: 515-525

[2] McGoldrick E, Stewart F, Parker R et al. Antenatal corticosteroids for accelerating fetal lung maturation for women at risk of preterm birth. Cochrane Database Syst Rev 2020; (12): CD004454

[3] NICE Guideline. Preterm labour and birth 2015. Accessed September 26, 2021 at: http://www.nice.org.uk/guidance/ng25

[4] [Anonymous]. Committee Opinion No. 713: Antenatal Corticosteroid Therapy for Fetal Maturation. Obstet Gynecol 2017; 130: e102-e109

[5] Skoll A, Boutin A, Bujold E et al. No. 364-Antenatal Corticosteroid Therapy for Improving Neonatal Outcomes. J Obstet Gynaecol Can 2018; 40: 1219-1239

[6] Berger R, Abele H, Bahlmann F et al. Prevention and Therapy of Preterm Birth. Guideline of the DGGG, OEGGG and SGGG (S2 k Level, AWMF Registry Number 015/025, February 2019) - Part 2 with Recommendations on the Tertiary Prevention of Preterm Birth and the Management of Preterm Premature Rupture of Membranes. Geburtshilfe Frauenheilkd 2019; 79: 813-833

[7] Kemp MW, Newnham JP, Challis JG et al. The clinical use of corticosteroids in pregnancy. Hum Reprod Update 2016; 22: 240-259

[8] Ballard PL, Ballard RA. Scientific basis and therapeutic regimens for use of antenatal glucocorticoids. Am J Obstet Gynecol 1995; 173: 254-262

[9] Egerman RS, Mercer BM, Doss JL et al. A randomized, controlled trial of oral and intramuscular dexamethasone in the prevention of neonatal respiratory distress syndrome. Am J Obstet Gynecol 1998; 179: 11201123

[10] Roberts D, Brown J, Medley N et al. Antenatal corticosteroids for accelerating fetal lung maturation for women at risk of preterm birth. Cochrane Database Syst Rev 2017; (3): CD004454

[11] Berry LM, Polk DH, Ikegami M et al. Preterm newborn lamb renal and cardiovascular responses after fetal or maternal antenatal betamethasone. Am J Physiol 1997; 272: R1972-R1979

[12] Cole TJ, Short KL, Hooper SB. The science of steroids. Semin Fetal Neonatal Med 2019; 24: 170-175

[13] Brownfoot FC, Gagliardi DI, Bain E et al. Different corticosteroids and regimens for accelerating fetal lung maturation for women at risk of preterm birth. Cochrane Database Syst Rev 2013; (8): CD006764

[14] Crowther CA, Ashwood P, Andersen CC et al.; ASTEROID Study Group. Maternal intramuscular dexamethasone versus betamethasone before preterm birth (ASTEROID): a multicentre, double-blind, randomised controlled trial. Lancet Child Adolesc Health 2019; 3: 769-780

[15] Ciapponi A, Klein K, Colaci D et al. Dexamethasone versus betamethasone for preterm birth: a systematic review and network meta-analysis. Am J Obstet Gynecol MFM 2021; 3: 100312

[16] Ballard PL. Hormones and lung maturation. Monogr Endocrinol 1986; 28: 1-354

[17] Howie RN, Liggins GC. The New Zealand Study of antepartum Glucocorticoid Treatment in Lung Development. In: Farell PM, ed. Biological and clinical Perspectives Vol II. New York: Academic Press; 1982: 255-265 
[18] Jobe AH, Moss TJ, Nitsos I et al. Betamethasone for lung maturation: testing dose and formulation in fetal sheep. Am J Obstet Gynecol 2007; 197: 523.e1-523.e6

[19] Asztalos EV, Murphy KE, Matthews SG. A Growing Dilemma: Antenatal Corticosteroids and Long-Term Consequences. Am J Perinatol 2020. doi:10.1055/s-0040-1718573

[20] Jobe AH, Nitsos I, Pillow J] et al. Betamethasone dose and formulation for induced lung maturation in fetal sheep. Am J Obstet Gynecol 2009; 201: 611.e1-611.e7

[21] Schmidt AF, Kemp MW, Rittenschober-Böhm J et al. Low-dose betamethasone-acetate for fetal lung maturation in preterm sheep. Am J Obstet Gynecol 2018; 218: 132.e1-132.e9

[22] Schmitz T, Doret M, Sentilhes $L$ et al. Dose reduction of antenatal betamethasone in women at risk of very preterm delivery (BETADOSE trial). Am J Obstet Gynecol 2021; 224: S723

[23] Van den Bergh BRH, van den Heuvel MI, Lahti M et al. Prenatal developmental origins of behavior and mental health: The influence of maternal stress in pregnancy. Neurosci Biobehav Rev 2020; 117: 26-64

[24] Astiz M, Heyde I, Fortmann Ml et al. The circadian phase of antenatal glucocorticoid treatment affects the risk of behavioral disorders. Nat Commun 2020; 11: 3593

[25] Roberts D, Dalziel S. Antenatal corticosteroids for accelerating fetal lung maturation for women at risk of preterm birth. Cochrane Database Syst Rev 2006; (3): CD004454

[26] Khandelwal M, Chang E, Hansen C et al. Betamethasone dosing interval: 12 or 24 hours apart? A randomized, noninferiority open trial. Am J Obstet Gynecol 2012; 206: 201.e1-201.e11

[27] Norman M, Piedvache A, Borch K et al. Association of Short Antenatal Corticosteroid Administration-to-Birth Intervals With Survival and Morbidity Among Very Preterm Infants: Results From the EPICE Cohort. JAMA Pediatr 2017; 171: 678-686

[28] Liebowitz M, Clyman RI. Antenatal Betamethasone: A Prolonged Time Interval from Administration to Delivery Is Associated with an Increased Incidence of Severe Intraventricular Hemorrhage in Infants Born before 28 Weeks Gestation. J Pediatr 2016; 177: 114-120.e1

[29] Levin HI, Ananth CV, Benjamin-Boamah C et al. Clinical indication and timing of antenatal corticosteroid administration at a single centre. BJOG 2016; 123: 409-414

[30] Berger R, Abele H, Bahlmann F et al. Prevention and Therapy of Preterm Birth. Guideline of the DGGG, OEGGG and SGGG (S2k Level, AWMF Registry Number 015/025, February 2019) - Part 1 with Recommendations on the Epidemiology, Etiology, Prediction, Primary and Secondary Prevention of Preterm Birth. Geburtshilfe Frauenheilkd 2019; 79: 800812

[31] Adams TM, Kinzler WL, Chavez MR et al. The timing of administration of antenatal corticosteroids in women with indicated preterm birth. Am J Obstet Gynecol 2015; 212: 645.e1-645.e4

[32] Makhija NK, Tronnes AA, Dunlap BS et al. Antenatal corticosteroid timing: accuracy after the introduction of a rescue course protocol. Am J Obstet Gynecol 2016; 214: 120.e1-120.e6

[33] Crowther CA, Middleton PF, Voysey M et al. Effects of repeat prenatal corticosteroids given to women at risk of preterm birth: An individual participant data meta-analysis. PLoS Med 2019; 16: e1002771

[34] Uno $\mathrm{H}$, Lohmiller L, Thieme $\mathrm{C}$ et al. Brain damage induced by prenatal exposure to dexamethasone in fetal rhesus macaques. I. Hippocampus. Brain Res Dev Brain Res 1990; 53: 157-167

[35] French NP, Hagan R, Evans SF et al. Repeated antenatal corticosteroids: size at birth and subsequent development. Am J Obstet Gynecol 1999; 180: $114-121$

[36] French NP, Hagan R, Evans SF et al. Repeated antenatal corticosteroids: effects on cerebral palsy and childhood behavior. Am J Obstet Gynecol 2004; 190: 588-595
[37] Asztalos EV, Murphy KE, Willan AR et al. Multiple courses of antenatal corticosteroids for preterm Birth study outcomes in children at 5 years of age (MACS-5). JAMA Pediatr 2013; 167: 1102-1110

[38] Wapner RJ, Sorokin Y, Mele L et al. Long-term outcomes after repeat doses of antenatal corticosteroids. N Engl J Med 2007; 357: 1190-1198

[39] Zephyrin LC, Hong KN, Wapner RJ et al. Gestational age-specific risks vs. benefits of multicourse antenatal corticosteroids for preterm labor. Am J Obstet Gynecol 2013; 209: 330.e1-330.e7

[40] Wapner R], Sorokin Y, Thom EA et al. Single versus weekly courses of antenatal corticosteroids: evaluation of safety and efficacy. Am J Obstet Gynecol 2006; 195: 633-642

[41] Anderson JG, Baer RJ, Partridge JC et al. Survival and Major Morbidity of Extremely Preterm Infants: A Population-Based Study. Pediatrics 2016; 138: e20154434

[42] Hibbard JU, Wilkins I, Sun L et al. Respiratory morbidity in late preterm births. JAMA 2010; 304: 419-425

[43] Gyamfi-Bannerman C, Thom EA, Blackwell SC et al. Antenatal Betamethasone for Women at Risk for Late Preterm Delivery. N Engl J Med 2016; 374: $1311-1320$

[44] Saccone G, Berghella V. Antenatal corticosteroids for maturity of term or near term fetuses: systematic review and meta-analysis of randomized controlled trials. BMJ 2016; 355: i5044

[45] Deshmukh M, Patole S. Antenatal corticosteroids for impending late preterm (34-36 + 6 weeks) deliveries-A systematic review and meta-analysis of RCTs. PLoS One 2021; 16: e0248774

[46] Stutchfield P, Whitaker R, Russell I. Antenatal betamethasone and incidence of neonatal respiratory distress after elective caesarean section: pragmatic randomised trial. BMJ 2005; 331: 662

[47] Stutchfield PR, Whitaker R, Gliddon AE et al. Behavioural, educationa and respiratory outcomes of antenatal betamethasone for term caesarean section (ASTECS trial). Arch Dis Child Fetal Neonatal Ed 2013; 98: F195-F200

[48] Räikkönen K, Gissler M, Kajantie E. Associations Between Maternal Antenatal Corticosteroid Treatment and Mental and Behavioral Disorders in Children. JAMA 2020; 323: 1924-1933

[49] Schittny ], Burry P. Development and Growth of the Lung. In: Fishman A, ed. Fishman's pulmonary Diseases and Disorders. McGraw Hill Medical; 2008: 91-115

[50] Frühgeborene an der Grenze der Lebensfähigkeit. Accessed March 28 , 2021 at: https://www.awmf.org/leitlinien/detail/ll/024-019.html

[51] Agarwal P, Sriram B, Rajadurai VS. Neonatal outcome of extremely preterm Asian infants $\leq 28$ weeks over a decade in the new millennium. J Perinatol 2015; 35: 297-303

[52] Fellman V, Hellström-Westas L, Norman M et al. One-year survival of extremely preterm infants after active perinatal care in Sweden. JAMA 2009; 301: 2225-2233

[53] Markestad T, Kaaresen PI, Rønnestad A et al. Early death, morbidity, and need of treatment among extremely premature infants. Pediatrics 2005; 115: 1289-1298

[54] Stensvold H], Klingenberg C, Stoen R et al.; Norwegian Neonatal Network. Neonatal Morbidity and 1-Year Survival of Extremely Preterm Infants. Pediatrics 2017; 139: e20161821

[55] Costeloe KL, Hennessy EM, Haider S et al. Short term outcomes after extreme preterm birth in England: comparison of two birth cohorts in 1995 and 2006 (the EPICure studies). BM] 2012; 345: e7976

[56] Costeloe K, Hennessy E, Gibson AT et al. The EPICure study: outcomes to discharge from hospital for infants born at the threshold of viability. Pediatrics 2000; 106: 659-671

[57] Hayes EJ, Paul DA, Stahl GE et al. Effect of antenatal corticosteroids on survival for neonates born at 23 weeks of gestation. Obstet Gynecol 2008; 111: 921-926 
[58] Tyson JE, Parikh NA, Langer ] et al. Intensive care for extreme prematurity-moving beyond gestational age. N Engl J Med 2008; 358: 1672-1681

[59] Bader D, Kugelman A, Boyko V et al. Risk factors and estimation tool for death among extremely premature infants: a national study. Pediatrics 2010; 125: 696-703

[60] Mori R, Kusuda S, Fujimura M. Antenatal corticosteroids promote survival of extremely preterm infants born at 22 to 23 weeks of gestation. | Pediatr 2011; 159: 110-114.e1
[61] Carlo WA, McDonald SA, Fanaroff AA et al. Association of antenatal corticosteroids with mortality and neurodevelopmental outcomes among infants born at 22 to 25 weeks' gestation. JAMA 2011; 306: 2348-2358

[62] Deshmukh M, Patole S. Antenatal corticosteroids for neonates born before 25 Weeks-A systematic review and meta-analysis. PLoS One 2017; 12: e0176090 